\title{
Immune response profile of caruncular and trophoblast cell lines infected by high- (Nc-Spain7) and low-virulence (Nc-Spain1H) isolates of Neospora caninum
}

\author{
Laura Jiménez-Pelayo ${ }^{1 \dagger}$, Marta García-Sánchez ${ }^{1 \dagger}$, Javier Regidor-Cerrillo ${ }^{1}$, Pilar Horcajo ${ }^{1}$, \\ Esther Collantes-Fernández ${ }^{1}$, Mercedes Gómez-Bautista' ${ }^{1}$ Nina Hambruch², Christiane Pfarrer ${ }^{2}$ \\ and Luis Miguel Ortega-Mora ${ }^{1^{*}}$
}

\begin{abstract}
Background: Bovine neosporosis, one of the main causes of reproductive failure in cattle worldwide, poses a challenge for the immune system of pregnant cows. Changes in the Th-1/Th-2 balance in the placenta during gestation have been associated with abortion. Cotyledon and caruncle cell layers form the maternal-foetal interface in the placenta and are able to recognize and induce immune responses against Neospora caninum among other pathogens. The objective of the present work was to elucidate the immunomodulation produced by high- (Nc-Spain7) and lowvirulence ( $\mathrm{Nc}$-Spain $1 \mathrm{H})$ isolates of $\mathrm{N}$. caninum in bovine trophoblast (F3) and caruncular cells (BCEC-1) at early and late points after infection. Variations in the mRNA expression levels of toll-like receptor-2 (TLR-2), Th1 and Th2 cytokines (IL-4, IL-10, IL-8, IL-6, IL-12p40, IL-17, IFN- $\gamma$, TGF- $\beta 1$, TNF- $\alpha$ ), and endothelial adhesion molecules (ICAM-1 and VCAM-1) were investigated by RT-qPCR, and protein variations in culture supernatants were investigated by ELISA.

Results: A similar pattern of modulation was found in both cell lines. The most upregulated cytokines in infected cells were pro-inflammatory TNF-a $(P<0.05-0.0001)$ and IL-8 $(P<0.05-0.001)$ whereas regulatory IL-6 $(P<0.05-0.001)$ and TGF- $\beta 1(P<0.05-0.001)$ were downregulated in both cell lines. The measurement of secreted IL-6, IL-8 and TNF-a confirmed the mRNA expression level results. Differences between isolates were found in the mRNA expression levels of TLR-2 $(P<0.05)$ in both cell lines and in the mRNA expression levels $(P<0.05)$ and protein secretion of TNF-a $(P<0.05)$, which were higher in the trophoblast cell line $(F 3)$ infected with the low-virulence isolate $\mathrm{Nc}$-Spain $1 \mathrm{H}$.

Conclusions: Neospora caninum infection is shown to favor a pro-inflammatory response in placental target cells in vitro. In addition, significant immunomodulation differences were observed between high- and low-virulence isolates, which would partially explain the differences in virulence.
\end{abstract}

Keywords: Neospora caninum, Cattle, Immune response, Placenta, Trophoblast, Caruncle, Isolates, Virulence, Cytokines

\footnotetext{
*Correspondence: luis.ortega@ucm.es

†Laura Jiménez-Pelayo and Marta García-Sánchez contributed equally to

this work

1 SALUVET, Animal Health Department, Complutense University

of Madrid, Ciudad Universitaria s/n, 28040 Madrid, Spain

Full list of author information is available at the end of the article
}

(c) The Author(s) 2019. This article is distributed under the terms of the Creative Commons Attribution 4.0 International License (http://creativecommons.org/licenses/by/4.0/), which permits unrestricted use, distribution, and reproduction in any medium, provided you give appropriate credit to the original author(s) and the source, provide a link to the Creative Commons license, and indicate if changes were made. The Creative Commons Public Domain Dedication waiver (http://creativecommons.org/ publicdomain/zero/1.0/) applies to the data made available in this article, unless otherwise stated. 


\section{Background}

Bovine neosporosis is one of the main transmissible causes of abortion in cattle worldwide [1-3]. The etiological agent of bovine neosporosis is Neospora caninum, an obligate intracellular parasite closely related to the zoonotic agent Toxoplasma gondii. Transplacental transmission is the main route of transmission in cattle [4] and the placenta can play a key role in the pathogenesis of bovine neosporosis $[5,6]$. The direct damage produced by the multiplication of the parasite in placental and foetal tissues has been proposed as one of the possible causes of abortion observed during $N$. caninum infections. Importantly, the placenta is considered to be an immune regulatory organ since it acts as a modulator of foetal and maternal immune responses. In fact, an immune-mediated pathogenesis has also been suggested as a possible cause of abortion [7]. It has been shown that the multiplication of the parasite in the placenta alters the immunological balance at the maternal-foetal interface with an increase of local pro-inflammatory IFN- $\gamma$, IL-12p40 and TNF- $\alpha$ cytokines which could compromise the gestation, together with an increase in IL-4 and IL-10 levels [8, 9], which avoids the immunological rejection of the foetus but favours the multiplication and vertical transmission of the parasite $[5,10]$. Trophoblast and caruncular cells are able to recognize pathogens and secrete cytokines and chemokines that recruit immune cells in the damaged area [11-13]. Thus, both cell types play a fundamental role in the initiation of innate immune responses at the placental level as well as in the development of an adaptative immune response for the pregnant dam and foetus.

Previous in vivo studies have shown the influence of the isolate on the dynamics and outcome of the infection in pregnant bovine models and in the cytokine profiles induced during the infection $([9,14-16]$, Jiménez-Pelayo et al. unpublished data). To date, only one recent study has utilized an in vitro model consisting of immortalized bovine trophoblasts (F3) from the foetus and caruncular cells (BCEC-1) from the dam. The aim of the study was to elucidate the interactions between tachyzoites and the host cells that resemble the maternal-foetal interface of the bovine placentome while also taking into account the influence of the isolate. Maternal cells, where both isolates showed similar phenotypic traits, presented higher resistance to the infection than trophoblast cells, where the high- (Nc-Spain7) and the low-virulence (NcSpain1H) isolates showed marked differences in proliferation [17].

However, the interactions between the parasite and the placental target cells from an immunological point of view have not been investigated in vitro until now. Thus, the objective of the present study was to compare the immune response profiles of the bovine placental cells in vitro after the infection with two $N$. caninum isolates of different virulence. Messenger RNA expression levels of TLR-2, pro-inflammatory cytokines IL-8, IL-12p40, IL-17, IFN- $\gamma$, TNF- $\alpha$, anti-inflammatory/regulatory cytokines TGF- $\beta 1$, IL-4, IL- 6 and IL-10 as well as ICAM-1 and VCAM-1 endothelial adhesion molecules were determined at 4 and 24 hours post-infection (hpi) in maternal caruncular (BCEC-1) and foetal trophoblast (F3) cell cultures and protein secretion was assessed in culture supernatants by ELISA.

\section{Results}

\section{Expression profile of TLR-2}

Our results showed that $N$. caninum infection for $4 \mathrm{~h}$ in BCEC-1 cells resulted in a significant upregulation of TLR-2 expression in Nc-Spain1H-infected cells compared with that of negative control cells (Kruskal-Wallis H-test followed by Dunn's multiple comparison test: $X^{2}=16.2$, $d f=2, P=0.0001)$ and with that of BCEC-1 cells infected with the high-virulence isolate Nc-Spain7 (Mann-Whitney U-test: $\left.U_{(8)}=8, Z=2.591, P=0.0007\right)$. In F3 cultures, statistical significance was not found at either 4 or $24 \mathrm{hpi}$ between infected groups and the control group. However, comparing both isolates, lower expression of TLR-2 was found in the F3 cultures infected with Nc-Spain7 than in the F3 cultures infected with the low-virulence isolate $\mathrm{Nc}-$ Spain1H at 4 hpi (Mann-Whitney U-test: $U_{(8)}=16$, $Z=2.287, P=0.0315$ ) (Fig. 1a).

\section{Pro-inflammatory and regulatory cytokine modulation}

The pro-inflammatory cytokines IL-8 (Kruskal-Wallis H-test: $\chi^{2}=19.52, d f=2, P<0.0001$ in BCEC- 1 and $\chi^{2}=17.56, d f=2, P=0.0002$ in F3) and TNF- $\alpha$ (KruskalWallis H-test: $X^{2}=19.73, d f=2, P<0.0001$ in BCEC-1 and $\chi^{2}=19.4, d f=2, P<0.0001$ in F3) were upregulated in both cell types at $4 \mathrm{hpi}$ compared to the respective control groups (Fig. 1b, c). At 24 hpi, IL-8 expression was still increased in BCEC-1 cells infected by both isolates (Kruskal-Wallis H-test followed by Dunn's multiple comparison test: $\chi^{2}=16.63, d f=2, P=0.0003$ and $X^{2}=10.19, d f=2, P=0.0117$ for Nc-Spain7 and NcSpain $1 \mathrm{H}$, respectively); however, the increment of IL-8 had disappeared at $24 \mathrm{hpi}$ in F3-infected cells with respect to the control group. When both isolates were compared, Nc-Spain1H induced a higher expression of TNF- $\alpha$ than the high-virulence isolate Nc-Spain7 at 4 hpi in F3 cells (Mann-Whitney U-test: $U_{(8)}=0, Z=2.579, P<0.0001$ ). Protein levels of the pro-inflammatory cytokines IL-8 and TNF- $\alpha$ were also investigated in the supernatant of control and infected cultures at different time-points post-infection. A higher secretion of IL-8 was found for both isolates in BCEC-1 cells at 24 hpi (Kruskal-Wallis 

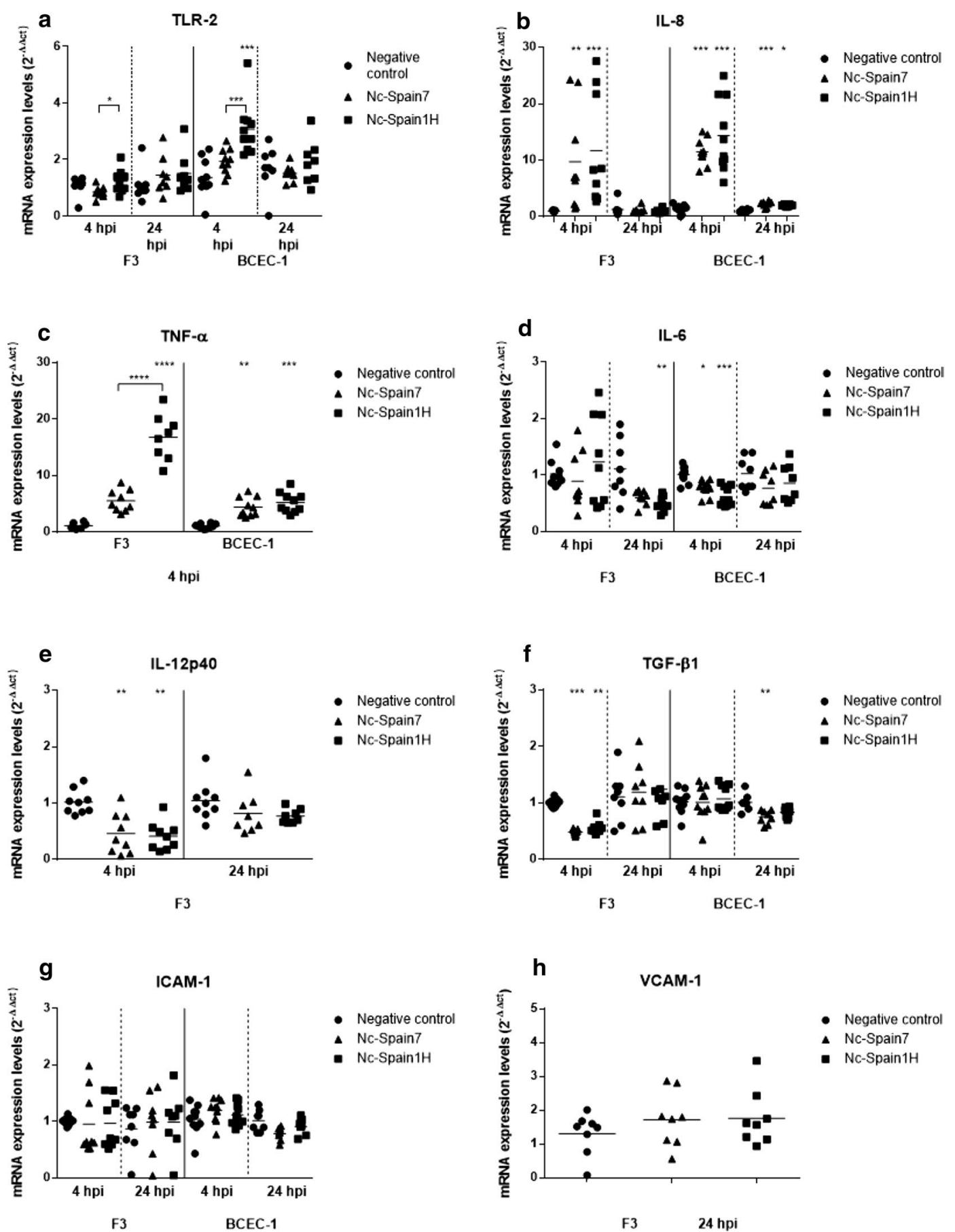

Fig. 1 TLR-2, IL-8, TNF-a, IL-6, IL-12p40, TGF- $\beta 1$, ICAM-1 and VCAM-1 transcript expression. Scatter-plot graphs of relative mRNA expression levels (as $x$-fold change) of TLR-2 (a), IL-8 (b), TNF-a (c), IL-6 (d), IL-12p40 (e), TGF- $\beta 1$ (f), ICAM-1 (g) and VCAM-1 (h) in F3 and BCEC-1 cell cultures at 4 and $24 \mathrm{hpi}$ with Nc-Spain7 and Nc-Spain1H isolates. Data are represented as individual points. Horizontal lines represent median values for each group. ${ }^{*}{ }^{* *} P<0.0001,{ }^{* *} P<0.001,{ }^{* *} P<0.01,{ }^{*} P<0.05$. Unbracketed symbols represent differences with respect to the control group, while significant differences between isolates are denoted by horizontal square brackets 
H-test: $\left.\chi^{2}=15.87, d f=2, P=0.0004\right)$ and in F3 cells at 56 hpi (Kruskal-Wallis H-test: $\chi^{2}=13.74, d f=2, P=0.001$ ) with respect to the control group (Fig. 2a, b). Secretion of TNF- $\alpha$ was higher in BCEC- 1 cells infected by both isolates (Kruskal-Wallis H-test: $\chi^{2}=18.9, d f=2, P<0.0001$; Fig. 2c) and in F3 cells infected by Nc-Spain1H (KruskalWallis H-test followed by Dunn's multiple comparison test: $\left.\chi^{2}=16, d f=2, P<0.0001\right)$ at $8 \mathrm{hpi}$, although an earlier secretion of TNF- $\alpha$ was also found in F3 cells infected by $\mathrm{Nc}-S p a i n 1 \mathrm{H}\left(\chi^{2}=14, d f=2, P=0.0003\right)$ at $4 \mathrm{hpi}$ (Fig. 2d, e). As observed with the TNF- $\alpha$ mRNA expression, Nc-Spain1H induced a higher secretion of TNF- $\alpha$ than did the high-virulence isolate Nc-Spain7 at $4 \mathrm{hpi}$ (Mann-Whitney U-test: $U_{(8)}=0, Z=2.736, P=0.0002$ ) and at $8 \mathrm{hpi}\left(U_{(8)}=0, Z=2.305, P=0.0002\right)$ in the F3 cultures (Fig. 2d, e).

The expression levels of other important cytokines associated with $N$. caninum infection, such as IL-12p40 and IL-6 (Fig. 1d, e), were modified in placental cells after parasite infection. Specifically, IL-6 levels were downregulated in BCEC-1 infected by Nc-Spain1H and NcSpain7 at 4 hpi (Kruskal-Wallis H-test: $\chi^{2}=16.08, d f=2$, $P=0.0003)$ and $\mathrm{F} 3$ cultures infected by Nc-Spain1H at 24 hpi $\left(\chi^{2}=10.5, d f=2, P=0.0052\right)$. IL-12p40 was also
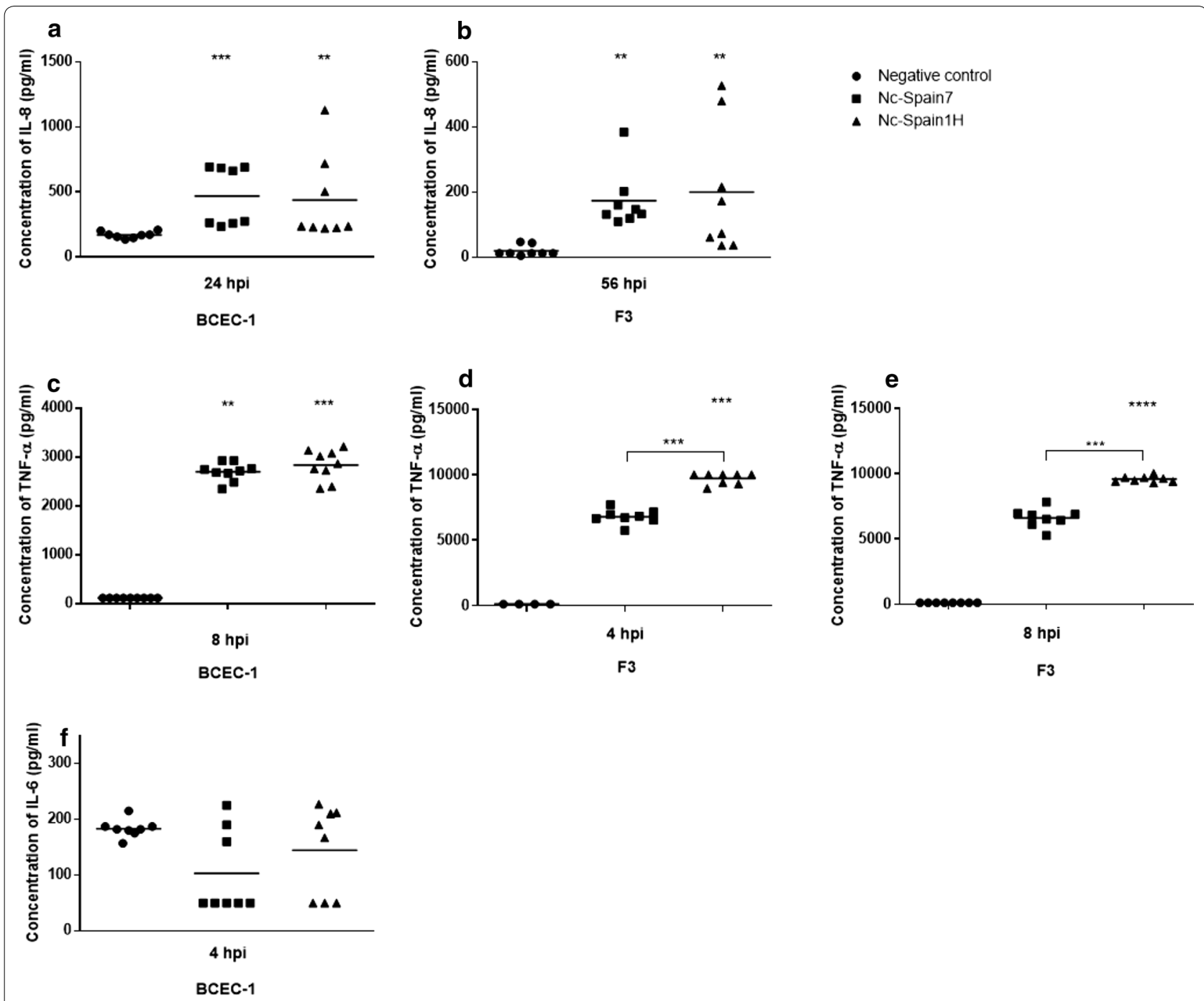

Fig. 2 IL-8, TNF-a and IL-6 secretion levels in culture supernatants. Scatter-plot graphs representing the concentration of IL-8 (pg/ml) in BCEC-1 (a) and F3 (b) supernatants infected with Nc-Spain7 and Nc-Spain $1 \mathrm{H}$ at 24 and 56 hpi, respectively, the concentration of TNF-a (pg/ml) in the BCEC-1 supernatants at $8 \mathrm{hpi}(\mathbf{c})$ and in the F3 supernatants at $4 \mathrm{hpi}(\mathbf{d})$ and $8 \mathrm{hpi}(\mathbf{e})$, and the concentration of IL-6 (pg/ml) in the BCEC-1 supernatants at 4 hpi (f). Data are represented as individual points. Horizontal lines represent median values for each group. ${ }^{* * *} P<0.0001$, ${ }^{* *} P<0.001$, ${ }^{* *} P<0.01$, ${ }^{*} P<0.05$. Unbracketed symbols represent differences with respect to the control group, while significant differences between isolates are denoted by horizontal square brackets 
downregulated but only in infected F3 cultures at 4 hpi $\left(x^{2}=12.99, d f=2, P=0.0015\right)$. Differences between isolates in the modulation of IL- 6 and IL-12p40 were not found. In addition, we observed that the caruncular cell layer did not express IL-12p40 mRNA at any time point. The decrease in the expression of IL- 6 observed in infected BCEC-1 cells was confirmed by the decrease in the secretion levels of that protein found in the supernatants from BCEC-1 cultures infected with both isolates at $4 \mathrm{hpi}$, although statistically significant differences were not found (Kruskal-Wallis H-test: $\chi^{2}=2.765$, $d f=2, P=0.251$ ), probably because of the high deviation between samples (Fig. 2f).

Finally, pro-inflammatory IL-17 and IFN- $\gamma$ responses were not detected in any cell lines at 4 nor at $24 \mathrm{hpi}$.

We also studied the mRNA levels of the anti-inflammatory cytokines TGF- $\beta 1$, IL- 4 and IL- 10 . Remarkably, we observed a decrease in the expression levels of TGF- $\beta 1$ in both cell lines infected with both isolates. Specifically, a decrease was observed at 4 hpi in F3 cultures (KruskalWallis H-test: $\left.\chi^{2}=18.44, d f=2, P<0.0001\right)$ and at 24 hpi in BCEC- 1 cultures $\left(\chi^{2}=12.02, d f=2, P=0.0025\right)$ (Fig. 1f). No differences between isolates were observed in the mRNA expression levels of TGF- $\beta 1$. There was not detection in bovine placental cells of the anti-inflammatory cytokine IL- 4 or the regulatory cytokine IL-10 at 4 and $24 \mathrm{hpi}$.

\section{Endothelial adhesion molecule (ICAM-1 and VCAM-1) expression}

The adhesion molecule ICAM-1 was expressed by both cell lines at 4 and 24 hpi. However, only a slight decrease in the mRNA expression levels of ICAM-1 was observed in the BCEC-1 cultures infected with Nc-Spain7 at $24 \mathrm{hpi}$ compared to the control group although statistical significance was not found (Kruskal-Wallis H-test: $\chi^{2}=5.894$, $d f=2, P=0.0525$ ) (Fig. 1g). VCAM-1 expression was detected only in the F3 cultures at 24 hpi, but differences between the infected and the control groups were not found in this culture at this time point (Fig. 1h).

Results of mRNA expression levels and protein secretion from statistical tests are reported in Additional file 1: Tables S1 and S2, respectively.

\section{Discussion}

Transmission of $N$. caninum across the placenta makes this organ key in the pathogenesis of bovine neosporosis. Innate immune signalling is crucial at the maternal-foetal interface, where vertical transmission of pathogens to the foetus can have profound pathological outcomes. Trophoblasts and other cell types within the placenta may also be involved in the physiological protection of the placenta [18]. Trophoblast cells have been shown to respond to some infections by producing pro-inflammatory cytokines and chemokines and endometrial or decidual cells can produce and secrete a variety of cytokines, participating in the attraction and activation of immune effector cells $[19,20]$. However, these innate immune mechanisms are unexplored at the maternal-foetal interface during $N$. caninum infection in pregnant cattle [21].

The expression of TLRs has been described in trophoblasts and other cell types within the placenta [22]. Specifically, TLR-2 was overexpressed in bovine trophoblast cell cultures at 8 hpi [23] and TLR-3, 7 and 8 have been implicated in $N$. caninum recognition in the bovine placenta [21, 24]. In our study, differential activation of TLR-2 in the F3 and BCEC-1 cultures was observed. An upregulation of TLR-2 was found in BCEC-1-infected cultures, especially in those infected with the low-virulence isolate Nc-Spain $1 \mathrm{H}$. The caruncular part of the placentome showed a higher expression of several TLRs, suggesting that the initial recognition of $N$. caninum at the placental level would occur in the maternal side of placenta [21]. Taking into account the data shown in Jiménez-Pelayo et al. [17], which confirm the higher proliferation of $N$. caninum in trophoblast cells, an important role of placental TLR-2 in the immune response against $N$. caninum seems plausible. TLR activation is crucial for initiating the innate immune responses responsible for the elimination of intracellular parasites such as $N$. caninum, and the signalling pathway activated by TLR-2 leads to an increase in the transcription factors NF- $\mathrm{k} \beta$ and AP- 1 , which trigger the synthesis of proinflammatory cytokines (TNF- $\alpha$, IL-6, IL-12 and IL-1 $\beta$ ) and chemokines (IL-8, RANTES) [25].

Despite differential modulation of host TLR-2, both cell types presented a similar variation in the IL-6, TNF- $\alpha$ and IL- 8 expression levels in infected cultures. The pro-inflammatory IL- 8 and TNF- $\alpha$ cytokines were upregulated, and secretion of the proteins in the supernatants of both cell lines was also detected by ELISA. IL-8, a cytokine with neutrophil chemotactic/activating and T-cell chemotactic activity both in vivo and in vitro, is important in the recruitment of leukocytes to the endometrium and may be a potential mediator of placental macrophage infiltration [26], which might help to eliminate the parasite. IL-8 upregulation has already been observed in bovine umbilical vein endothelial cells (BUVECs) infected by $T$. gondii and $N$. caninum [27] as well as in bovine trophoblastic cells and placentomes from cows infected with Brucella abortus [28]. TNF- $\alpha$ is an inflammatory cytokine whose expression has also been described for epithelial cells [29]. TNF- $\alpha$ is expressed in all cell types of the trophoblastic lineage and provokes a variety of biological effects on placental and endometrial cell types [29]. In addition, TNF- $\alpha$, through 
the NF- $\kappa \beta$ signalling pathway, coordinates the inflammatory response via the induction of other cytokines (IL-1 and IL-6) and chemokines (IL-8) and via the upregulation of adhesion molecules (ICAM-1 and VCAM-1) [30, 31], playing a role favouring protective immunity in infectious diseases [32]. There are several lines of experimental evidence indicating that TNF- $\alpha$ plays a role not only in immunity to $N$. caninum but also in the immunopathology of neosporosis. TNF- $\alpha$ expression and secretion may reduce the parasite presence in the placenta by inhibiting the intracellular multiplication of the parasite [33] and participating in parasite proliferation control mechanisms [34]; however, TNF- $\alpha$ expression is detrimental to pregnancy maintenance [8].

IL-6 expression levels were diminished in infected cultures of BCEC-1 and F3 at 4 and $24 \mathrm{hpi}$, respectively. The classification of IL- 6 as Th1 or Th 2 has been considered controversial since it can have characteristics of both depending on the dose, the cellular source and the gestational stage studied [35]. Currently, the presence of IL-6 displaces the Th1/Th2 balance towards a Th2 response [36]. However, in vivo models of N. caninum infection have shown IL-6 upregulation [37, 38, Jiménez-Pelayo et al. unpublished data]. This response pattern may be related to a protective action that protects the foetus and allows gestation even if the animals are born infected [10]. The decrease in IL-6 observed could be explained by the following: (i) IL-6 expression levels were affected by the high antigenic dose administered (MOI 10), resulting in downregulation [39]; (ii) the time points were not adequate for detecting the peak of IL- 6 expression, and the observed decrease may be the consequence of the rapid reduction in IL-6 expression after a peak of expression [40-42]; or (iii) other cell types are implicated in the upregulation of IL-6 that was observed in vivo.

The anti-inflammatory cytokine TGF- $\beta 1$ was also found to be downregulated in F3 and BCEC-1 cultures at 4 and 24 hpi, respectively. Several members of the TGF- $\beta$ superfamily have been suggested to regulate trophoblast cell functions, and their dysregulation has been implicated in pregnancy-associated diseases. TGF- $\beta 1$ is crucial in neutralizing the inflammatory responses induced by Th1-type cytokines [5]. This effect has already been observed in previous works where the reduction of TGF$\beta 1$ was shown to be beneficial for controlling $N$. caninum growth but detrimental for the adequate maintenance of pregnancy $[38,43]$.

The reduction of pro-inflammatory IL-12p40 observed in trophoblast cells, together with the lack of expression of IL-12p40 in BCEC-1 cultures, disagrees with the results of previous experimental infections $[8,9,38,44$, 45]. Similarly, the lack of expression of pro-inflammatory IFN- $\gamma$, essential for controlling parasite infection $[1,46]$, and anti-inflammatory IL-4 and IL-10, related to placental protection during $N$. caninum infections [8, 9], lead us to hypothesize that the upregulation of IL-12p40, IFN- $\gamma$, IL-4 and IL-10 observed in vivo could be attributed to immune cells present in the placenta, such as dendritic cells, NK cells or macrophages. Therefore, trophoblast and/or caruncular cells would not be responsible for the direct production of these cytokines, although the assayed time points may not have been appropriate for their detection.

Finally, ICAM-1 and VCAM-1 expression were not modulated by the parasite infection. These adhesion molecules participate in the recruitment of inflammatory immune cells [47] and promote the adherence of monocytes to endothelial cells [48]. The upregulation of ICAM-1 has been observed in in vitro infections with apicomplexan parasites $[27,49,50]$. The absence of modulation observed in this work may be explained by differences in the timing of the expression of ICAM-1 and VCAM-1 $[27,49,50]$ or by the lack of stimuli such as the acute-phase protein C-reactive protein (CRP), which is produced by the liver in response to IL-6 [51].

As mentioned above, the parasite isolate is a key factor in the outcome of the infection. In general, differences in the modulation between high- and low-virulence isolates were not remarkable in trophoblast or caruncular cells, with the exception of the mRNA expression levels of TLR-2 and TNF- $\alpha$. TLR-2 levels were more upregulated by Nc-Spain1H infection than by Nc-Spain7 infection in both cell lines, which led us to hypothesize that the high-virulence isolate would activate less of the TLR recognition system, reducing the immune responses triggered by TLR-2. The inhibition of the TLRs implicated in the recognition of Trypanosoma cruzi and T. gondii in HPCVE increased the parasite burden and, importantly, TLR-2 inhibition prevented the secretion of IL-6 and IL-10, increasing parasite damage $[52,53]$. The lowvirulence isolate $\mathrm{Nc}$-Spain $1 \mathrm{H}$ activates the expression of TLR-2, starting an inflammatory response, which may be the cause of the lower proliferation of this isolate [17, 54 ] in addition to being one of the causes that explains the higher levels of TNF- $\alpha$ in Nc-Spain1H-infected cells, especially in trophoblast cells. Our results suggest that differential activation of the TLRs by the isolates of differing virulences should be subject to future research since they may be responsible for the biological differences observed both in vitro and in vivo.

The low-virulence isolate $\mathrm{Nc}$-Spain $1 \mathrm{H}$ also induced higher expression of TNF- $\alpha$ in F3. A higher TNF- $\alpha$ response may more efficiently control the proliferation of Nc-Spain1H in F3 cultures, which could explain the observations made by Jiménez-Pelayo et al. [17] where lower proliferation of $\mathrm{Nc}$-Spain $1 \mathrm{H}$ was observed in these 
cells. The lower expression of TNF- $\alpha$ observed during the early stage of infection of trophoblasts with the highvirulence isolate Nc-Spain7 supports the hypothesis that this isolate may modify by yet unknown mechanisms the pro-inflammatory response by trophoblast cells. However, how Nc-Spain7 is able to evade the immune response and maintain lower levels of TNF- $\alpha$ expression in F3 remains unknown. On the other hand, these results suggest that pro-inflammatory cytokines such as TNF- $\alpha$ could have a minor impact in placental damage than postulated in previous works $[8,55]$, but other mechanisms should be implicated in placental damage in vivo and the occurrence of abortion, such as the high multiplication ability showed by the high-virulence isolate Nc-Spain7 [17].

\section{Conclusions}

The results presented in this manuscript suggest that placental cells participate in the innate immune response at the maternal-foetal interface via a rapid pro-inflammatory response characterized by the overexpression of IL- 8 and TNF- $\alpha$ and the downregulation of TGF- $\beta 1$ and IL-6. Slight differences were detected when the immunomodulatory response induced by the high and low virulent $N$. caninum isolates was compared. The higher expression of TLR-2 in the F3 and BCEC-1 cells and the TNF- $\alpha$ in F3 cells infected with the low-virulence isolate $\mathrm{Nc}-\mathrm{Spain} 1 \mathrm{H}$ may indicate a higher stimulation of the immune response by this isolate or a higher immunomodulation of Nc-Spain7, which could explain the biological differences observed in vitro and in vivo. F3 and BCEC-1 cultures seem to be a good tool for the study of the TLR activation mechanisms by $N$. caninum. Finally, we observed that cytokines such as IFN- $\gamma$, IL-4 or IL-10, which are commonly upregulated in the placenta after $N$. caninum infection, are not expressed in F3 and BCEC-1 cells; we conclude that the trophoblast and caruncular epithelial cells are not implicated in the production of these cytokines in the placenta or that other pathways/ cells/molecules are needed for their production.

\section{Methods}

\section{Parasites and cell cultures}

A full description of the Nc-Spain1H and Nc-Spain7 parasites and cell cultures of bovine caruncular epithelial (BCEC-1) and bovine trophoblast cells (F3) is provided in a previous report [17]. Briefly, Nc-Spain7 and $\mathrm{Nc}-S p a i n 1 \mathrm{H}$ isolates were obtained from healthy, congenitally infected calves [56, 57] and tachyzoites were maintained in a MARC-145 culture as described previously [54]. The number of culture passages of both $N$. caninum isolates was limited (passages from 9 to 11) to maintain their biological in vivo behavior [58].
The BCEC-1 and F3 cell lines were kindly donated by Dr C. Pfarrer from the University of Veterinary Medicine Hannover and maintained following the protocols described in the literature $[59,60]$.

\section{Infection of the cultures, collection and preservation of the samples}

BCEC- 1 and F3 cells were seeded in $25 \mathrm{~cm}^{2}$ culture flasks adjusting the number of cells in order to obtain a confluent monolayer after $24 \mathrm{~h}$ of culture. F3 was seeded at $10^{6}$ cells per flask, whereas BCEC- 1 was seeded at a concentration of $2 \times 10^{6}$ cells per flask. Tachyzoites were recovered from MARC-145 cultures when most of the parasites were still inside parasitophorous vacuoles; tachyzoites were purified using disposable PD-10 Desalting Columns (G.E. Healthcare, Amersham, UK) as previously described [54]. The parasite viability was checked by trypan blue exclusion, and the tachyzoites were counted. Multiplicity of infection (MOI) of $8\left(8 \times 10^{6}\right.$ tachyzoites in F3 and $16 \times 10^{6}$ tachyzoites in BCEC-1) and $10\left(10^{7}\right.$ tachyzoites in F3 and $2 \times 10^{7}$ tachyzoites in BCEC-1) from the Nc-Spain7 and Nc-Spain1H isolates, respectively, were inoculated into confluent monolayers of F3 and BCEC-1 quickly after collection. Due to the differences observed in the infection rate between isolates [17], different MOIs of each isolate were selected with the aim of obtaining cultures infected with the same quantity of each parasite at 4 and $24 \mathrm{hpi}$. This way possible differences in the modulation of the mRNA expression levels between isolates could be attributed to differences in their biological behavior and not to the differences in the parasite burden. In addition, cultures were infected with high doses of both parasites to get a high infection of the cultures at 4 and 24 hpi so that the RNA from uninfected cells did not mask possible differences in RNA expression levels induced by the infection. The flasks were incubated at $37{ }^{\circ} \mathrm{C}$ until collection of the samples. The supernatants were collected at different time points $(4,8,24$ and $56 \mathrm{hpi}$ ) and stored at $-80^{\circ} \mathrm{C}$ for the detection of proteins by ELISA. The cultures were harvested at 4 or $24 \mathrm{hpi}$ by scraping, centrifugation at $1350 \times g$ for $15 \mathrm{~min}$ at $4{ }^{\circ} \mathrm{C}$ and resuspending the pellet in $300 \mu \mathrm{l}$ of RNAlater ${ }^{\circledR}$ (Qiagen, Hilden, Germany). The samples were stored at $-80{ }^{\circ} \mathrm{C}$ prior to RNA extraction.

Two independent experiments were carried out and four replicates were obtained in each experiment.

\section{RNA extraction, reverse transcription and quantitative real-time PCR}

The mRNA expression levels of TLR-2, pro-inflammatory cytokines IL-6, IL-8, IL-12p40, IL-17, IFN- $\gamma$, TNF$\alpha$, anti-inflammatory/regulatory cytokines TGF- $\beta 1$, IL-4 and IL-10 as well as ICAM-1 and VCAM-1 endothelial 
adhesion molecules were determined by real-time RTPCR in the F3 and BCEC-1 cell layers infected with the high-virulence isolate (Nc-Spain7) and the low-virulence isolate (Nc-Spain1H) of $N$. caninum at an early (4 hpi) and a late (24 hpi) time point.

RNA was extracted using a commercial Maxwell ${ }^{\circledR}$ 16 LEV simplyRNA Purification kit (Promega, Madison, WI, USA) following the manufacturer's recommendations. RNA integrity was checked by $1 \%$ agarose gel and RNA concentrations were determined using a NanoPhotometer ${ }^{\circledR}$ spectrophotometer (Implen, Munich, Germany). cDNA was obtained by reverse transcription of $2.5 \mu \mathrm{g}$ of RNA using the master mix SuperScript ${ }^{\circledR}$ VILO $^{\mathrm{TM}}$ cDNA Synthesis kit (Invitrogen, Paisley, UK), which was diluted 1:20 in molecular grade water for the qPCR assays.

The PCRs were performed using $12.5 \mu \mathrm{l}$ of Power SYBR $^{\circledR}$ Green PCR Master Mix (Applied Biosystems, Foster City, CA, USA), 10 pmol of each primer (except for TLR-2 primers which were used at a concentration of $22.5 \mathrm{pmol}$ ) and $5 \mu \mathrm{l}$ of diluted cDNA samples in an ABI 7300 Real Time PCR System (Applied Biosystems). The primers used for the qPCR reactions are shown in Table 1. $\beta$-Actin and GAPDH were used as housekeeping

Table 1 Sequences of primers used for cytokine real-time PCR (qPCR) and standard curve data

\begin{tabular}{|c|c|c|c|c|c|}
\hline Target $^{\mathrm{a}}$ & Primer & Primer sequence $\left(5^{\prime}-3^{\prime}\right)$ & Product size (bp) & $R^{2 b}$ & Slope ${ }^{c}$ \\
\hline \multirow[t]{2}{*}{ IFN- $\gamma\left(N M \_174086.1\right)$} & QIFN-UP9 & GATTCAAATTCCGGTGGATG & 110 & 0.994 & $(-3.47)-(-3.30)$ \\
\hline & QIFN-RPg & TTCTCTTCCGCTTTCTGAGG & & & \\
\hline \multirow[t]{2}{*}{ TNF-a (EU276079.1) } & QTNF-UP' & CCAGAGGGAAGAGCAGTCC & 126 & 0.998 & $(-3.39)-(-3.27)$ \\
\hline & QTNF-RP & GGAGAGTTGATGTCGGCTAC & & & \\
\hline \multirow[t]{2}{*}{ IL-4 (M77120.1) } & QIL4-UPg & CTGCCCCAAAGAACACAACT & 169 & 0.995 & $(-3.33)-(-3.54)$ \\
\hline & QIL4-RPg & GTGCTCGTCTTGGCTTCATT & & & \\
\hline \multirow[t]{2}{*}{ IL-6 (X68723.1) } & QIL-6-UPd & CTGGGTTCAATCAGGCGATT & 150 & 0.999 & $(-3.22)-(-3.20)$ \\
\hline & QIL-6-RPd & GGATCTGGATCAGTGTTCTGA & & & \\
\hline \multirow[t]{2}{*}{ IL-8 (BC103310.1) } & qlL8-Fw & CCACACCTTTCCACCCCAAA & 177 & 0.995 & $(-3.36)-(-3.23)$ \\
\hline & qlL8-Rw $w^{h}$ & CTTGCTTCTCAGCTCTCTTC & & & \\
\hline \multirow[t]{2}{*}{ IL-10 (NM_174088.1) } & QIL10-UPg & TGCTGGATGACTTTAAGGGTTACC & 60 & 0.999 & $(-3.27)-(-3.42)$ \\
\hline & QIL10-RPg & AAAACTGGATCATTTCCGACAAG & & & \\
\hline \multirow{2}{*}{ IL-12p40 (NM_174356.1) } & QIL12-UPg & AGTACACAGTGGAGTGTCAG & 157 & 0.992 & $(-3.39)-(-3.35)$ \\
\hline & QIL12-RPg & TTCTTGGGTGGGTCTGGTTT & & & \\
\hline \multirow[t]{2}{*}{ IL-17 (NM_001008412.1) } & qlL17bov-up ${ }^{h}$ & GAACTTCATCTATGTCACTGC & 83 & 0.997 & $(-3.30)-(-3.18)$ \\
\hline & qlL17bov-rev ${ }^{h}$ & TGGACTCTGTGGGATGATGA & & & \\
\hline \multirow[t]{2}{*}{ TGF- $\beta 1$ (NM_001009400.1) } & QTGF-UPd & GGTGGAATACGGCAACAAAA & 117 & 0.999 & $(-3.60)-(-3.53)$ \\
\hline & QTGF-RP ${ }^{d}$ & CGAGAGAGCAACACAGGTTC & & & \\
\hline \multirow[t]{2}{*}{ TLR-2 (NM_001048231.1) } & QTLR2-UPe & ACGACGCCTTTGTGTCCTAC & 192 & 0.993 & $(-3.74)-(-3.38)$ \\
\hline & QTLR2-RPe & CCGAAAGCACAAAGATGGTT & & & \\
\hline \multirow[t]{2}{*}{ ICAM-1 (NM_174348.2) } & qICAM-Fw $w^{h}$ & AGACCTATGTCCTGCCATCG & 219 & 0.994 & $(-3.34)-(-3.30)$ \\
\hline & qICAM-Rw ${ }^{h}$ & GGTGCCCTCCTCATTTTTCCT & & & \\
\hline \multirow[t]{2}{*}{ VCAM (XM_005204079.2) } & qVCAM-Fw ${ }^{h}$ & GAACTGGAAGTCTACATCTC & 128 & 0.998 & $(-3.36)-(-3.32)$ \\
\hline & qVCAM-Rw $w^{h}$ & CAGAGAATCCGTGGAGCTGG & & & \\
\hline \multirow[t]{2}{*}{ GAPDH (NM_001034034) } & GAPDH-F ${ }^{f}$ & ATCTCGCTCCTGGAAGATG & 227 & 0.996 & $(-3.67)-(-3.58)$ \\
\hline & GAPDH-R & TCGGAGTGAACGGATTCG & & & \\
\hline \multirow[t]{2}{*}{ B-Actin (NM_173979.3) } & BACTIN-UPg & ACACCGCAACCAGTTCGCCAT & 216 & 0.994 & $(-3.45)-(-3.36)$ \\
\hline & BACT216-RPg & GTCAGGATGCCTCTCTTGCT & & & \\
\hline
\end{tabular}

a NCBI accession numbers are for cDNA sequences used in primer design. Primer annealing was also checked with the Bos taurus genomic DNA sequences (http:// www.ncbi.nlm.nih.gov/nuccore)

${ }^{\mathrm{b}}$ Minimum coefficient of regression $\left(R^{2}\right)$ of standard curves for each PCR target in all batches of amplification

c Standard curve slopes. Minimum and maximum values for slopes for each PCR target in all batches of amplification

d Primer first described by Arraz-Solís et al. [43]

e Primer first described by Menzies \& Ingham [61]

f Primer first described by Puech et al. [62]

g Primer first described by Regidor-Cerrillo et al. [9]

h Primer described in the present work for the first time 
genes, obtaining comparable Ct values for all the samples. For each target gene, a seven-point standard curve was included in each batch of amplifications based on 10 -fold serial dilutions starting at $10 \mathrm{ng} / \mu \mathrm{l}$ of plasmid DNA. The relative quantification of the mRNA expression levels ( $\mathrm{x}$-fold change in expression) was carried out by the comparative $2^{-\Delta \Delta \mathrm{Ct}}$ method [63].

\section{Measurement of cytokines in supernatants of BCEC-1 and $\mathrm{F} 3$ cell cultures by ELISA}

Protein concentrations of the cytokines that showed variations in the mRNA expression levels were determined in the culture supernatants at 4, 8, 24 and 56 hpi using commercial ELISA kits. The levels of IL-6, IL- 8 and TNF- $\alpha$ cytokines were measured in the supernatants of the BCEC-1 and F3 cells by sandwich ELISAs using a Bovine IL-6 ELISA Reagent kit (ESS0029; Thermo Fisher Scientific, Waltham, MA, USA), Bovine IL-8 (CXCL8) ELISA Development kit (3114-1A-6; Mabtech AB, Stockholm, Sweden) and Bovine TNF- $\alpha$ ELISA kit (EBTNF; Thermo Fisher Scientific) following the manufacturers' instructions. The sensitivity limits of these assays were $78 \mathrm{pg} / \mathrm{ml}$ for IL-6, $25 \mathrm{pg} / \mathrm{ml}$ for IL-8 and $100 \mathrm{pg} / \mathrm{ml}$ for TNF- $\alpha$.

\section{Statistical analysis}

TLR, cytokine and endothelial adhesion molecule mRNA expression levels, as well as differences in the protein secretion between infected and control groups, were analysed using the non-parametric Kruskal-Wallis test, followed by Dunn's multiple comparison test for all pairwise comparisons. In addition, to assess differences between both infected groups a Mann-Whitney test was performed for each molecule analysed. The statistical significance for all the analyses was established with $P<0.05$. GraphPad Prism v.5.01 software (GraphPad Software, San Diego, CA, USA) was used to perform all statistical analyses and create all the graphical illustrations.

\section{Additional file}

Additional file 1:Table S1. Statistical test results for mRNA expression levels. Table S2. Statistical test results for protein secretion.

\section{Abbreviations}

BCEC-1: bovine caruncular epithelial cell line 1; F3: bovine placental trophoblast cell line; GPCR: real-time polymerase chain reaction; hpi: hours post-infection; BVD: bovine viral diarrhea; DMEM: Dulbecco's modified Eagle medium; FCS: foetal calf serum; PBS: phosphate buffered saline; TLR-2: Toll-like Receptor 2; IL: interleukin; IFN: interferon; TGF: transforming growth factor; TNF: tumoral necrosis factor; ICAM: intercellular adhesion molecule; VCAM: vascular cell adhesion molecule; ELISA: enzyme-linked immunosorbent assay; BUVECS: bovine umbilical vein endothelial cells; HPCVE: human placental chorionic villi explants; MOl: multiplicity of infection.
Acknowledgements

Not applicable.

\section{Funding}

This work was supported by the Spanish Ministry of Economy and Competitiveness (AGL2013-44694-R) and the Community of Madrid (PLATESA2-CM P2018/BAA-4370). Laura Jiménez-Pelayo was financially supported by a fellowship from the Complutense University of Madrid and Marta García-Sánchez was financially supported through a grant from the Spanish Ministry of Economy and Competitiveness (BES-2014-070723). The funders had no role in study design, data collection and analysis, decision to publish, or preparation of the manuscript.

\section{Availability of data and materials}

Not applicable.

\section{Authors' contributions}

$J R C, P H, E C F, M G B$ and $L M O$ conceived the study and participated in its design. LJP and MGS wrote the manuscript, with interpretation of results and discussion input from JRC, ECF, MGB, LMO, NH and CP. LJP and MGS performed in vitro infection of the cultures, collection of the samples and ELISA assays. JRC, PH, LJP and MGS designed and performed RT-qPCR analyses. NH and CP isolated bovine trophoblast and caruncular cell lines used in the assays. LPP and MGS carried out statistical analyses and interpreted the results. All authors read and approved the final manuscript.

\section{Ethics approval and consent to participate}

Not applicable.

\section{Consent for publication}

Not applicable.

\section{Competing interests}

The authors declare that they have no competing interests.

\section{Publisher's Note}

Springer Nature remains neutral with regard to jurisdictional claims in published maps and institutional affiliations.

\section{Author details}

1 SALUVET, Animal Health Department, Complutense University of Madrid, Ciudad Universitaria s/n, 28040 Madrid, Spain. ${ }^{2}$ Department of Anatomy, University of Veterinary Medicine Hannover, Bischofsholer Damm 15, 30173 Hannover, Germany.

Received: 4 January 2019 Accepted: 29 April 2019

Published online: 08 May 2019

\section{References}

1. Innes EA, Wright S, Bartley P, Maley S, Macaldowie C, Esteban-Redondo I, et al. The host-parasite relationship in bovine neosporosis. Vet Immunol Immunopathol. 2005;108:29-36.

2. Dubey JP, Buxton D, Wouda W. Pathogenesis of bovine neosporosis. J Comp Pathol. 2006;134:267-89.

3. Dubey JP, Schares G, Ortega-Mora LM. Epidemiology and control of neosporosis and Neospora caninum. Clin Microbiol Rev. 2007;20:323-67.

4. Williams DJ, Hartley CS, Bjorkman C, Trees AJ. Endogenous and exogenous transplacental transmission of Neospora caninum - how the route of transmission impacts on epidemiology and control of disease. Parasitology. 2009;136:1895-900.

5. Entrican G. Immune regulation during pregnancy and host-pathogen interactions in infectious abortion. J Comp Pathol. 2002;126:79-94.

6. Innes EA. The host-parasite relationship in pregnant cattle infected with Neospora caninum. Parasitology. 2007;134:1903-10.

7. Quinn HE, Ellis JT, Smith NC. Neospora caninum: a cause of immunemediated failure of pregnancy? Trends Parasitol. 2002;18:391-4.

8. Rosbottom A, Gibney EH, Guy CS, Kipar A, Smith RF, Kaiser P, et al. Upregulation of cytokines is detected in the placentas of cattle infected with 
Neospora caninum and is more marked early in gestation when fetal death is observed. Infect Immun. 2008;76:2352-61.

9. Regidor-Cerrillo J, Arranz-Solis D, Benavides J, Gomez-Bautista M, Castro-Hermida JA, Mezo M, et al. Neospora caninum infection during early pregnancy in cattle: how the isolate influences infection dynamics, clinical outcome and peripheral and local immune responses. Vet Res. 2014:45:10.

10. Innes EA, Andrianarivo AG, Bjorkman C, Williams DJ, Conrad PA. Immune responses to Neospora caninum and prospects for vaccination. Trends Parasitol. 2002;18:497-504.

11. Montes MJ, Tortosa CG, Borja C, Abadia AC, González-Gómez F, Ruiz C, et al. Constitutive secretion of interleukin- 6 by human decidual stromal cells in culture. Regulatory effect of progesterone. Am J Reprod Immunol. 1995;34:188-94.

12. Steinborn A, Von Gall C, Hildenbrand R, Stutte H, Kaufmann M. Identification of placental cytokine-producing cells in term and preterm labor. Obstet Gynecol. 1998;91:329-35.

13. Steinborn A, Geisse M, Kaufmann M. Expression of cytokine receptors in the placenta in term and preterm labour. Placenta. 1998;19:165-70.

14. Rojo-Montejo S, Collantes-Fernández E, Blanco-Murcia J, RodríguezBertos A, Risco-Castillo V, Ortega-Mora LM. Experimental infection with a low virulence isolate of Neospora caninum at 70 days gestation in cattle did not result in foetopathy. Vet Res. 2009;40:49.

15. Caspe SG, Moore DP, Leunda MR, Cano DB, Lischinsky L, Regidor-Cerrillo J, et al. The Neospora caninum-Spain 7 isolate induces placental damage, fetal death and abortion in cattle when inoculated in early gestation. Vet Parasitol. 2012:189:171-81.

16. Dellarupe A, Regidor-Cerrillo J, Jimenez-Ruiz E, Schares G, Unzaga JM, Venturini $M C$, et al. Comparison of host cell invasion and proliferation among Neospora caninum isolates obtained from oocysts and from clinical cases of naturally infected dogs. Exp Parasitol. 2014;145:22-8.

17. Jiménez-Pelayo L, García-Sánchez M, Regidor-Cerrillo J, Horcajo P, Collantes-Fernández E, Gómez-Bautista M, et al. Differential susceptibility of bovine caruncular and trophoblast cell lines to infection with high and low virulence isolates of Neospora caninum. Parasit Vectors. 2017;10:463.

18. Bevilacqua E, Hoshida MS, Amarante-Paffaro A, Albieri-Borges A, Zago Gomes S. Trophoblast phagocytic program: roles in different placental systems. Int J Dev Biol. 2010;54:495-505.

19. Mitsunari M, Yoshida S, Shoji T, Tsukihara S, Iwabe T, Harada T, et al. Macrophage-activating lipopeptide-2 induces cyclooxygenase-2 and prostaglandin E2 via toll-like receptor 2 in human placental trophoblast cells. J Reprod Immunol. 2006:72:46-59.

20. Gillaux C, Mehats C, Vaiman D, Cabrol D, Breuiller-Fouche M. Functional screening of TLRs in human amniotic epithelial cells. J Immunol. 2011;187:2766-74.

21. Marin MS, Hecker YP, Quintana S, Pérez S, Leunda MR, Cantón G, et al. Toll-like receptors 3, 7 and 8 are upregulated in the placental caruncle and fetal spleen of Neospora caninum experimentally infected cattle. Vet Parasitol. 2017;236:58-61.

22. Koga K, Mor G. expression and function of Toll-like receptors at the maternal-fetal interface. Reprod Sci. 2008;15:231-42.

23. Horcajo P, Jimenez-Pelayo L, Garcia-Sanchez M, Regidor-Cerrillo J, Collantes-Fernandez E, Rozas D, et al. Transcriptome modulation of bovine trophoblast cells in vitro by Neospora caninum. Int J Parasitol. 2017:47:791-9.

24. Marin MS, Hecker YP, Quintana S, Pérez S, Leunda MR, Cantón G, et al. Immunization with inactivated antigens of Neospora caninum induces toll-like receptors 3, 7, 8 and 9 in maternal-fetal interface of infected pregnant heifers. Vet Parasitol. 2017;243:12-7.

25. Liu J, Cao X. Cellular and molecular regulation of innate inflammatory responses. Cell Mol Immunol. 2016;13:711.

26. Adams DH, Rlloyd A. Chemokines: leucocyte recruitment and activation cytokines. Lancet. 1997;349:490-5.

27. Taubert A, Krull M, Zahner H, Hermosilla C. Toxoplasma gondii and Neospora caninum infections of bovine endothelial cells induce endothelial adhesion molecule gene transcription and subsequent PMN adhesion. Vet Immunol Immunopathol. 2006;112:272-83.
28. Carvalho Neta AV, Stynen AP, Paixao TA, Miranda KL, Silva FL, Roux CM, et al. Modulation of the bovine trophoblastic innate immune response by Brucella abortus. Infect Immun. 2008;76:1897-907.

29. Haider S, Knöfler M. Human tumour necrosis factor: physiological and pathological roles in placenta and endometrium. Placenta. 2009;30:111-23.

30. Haraldsen G, Kvale D, Lien B, Farstad IN, Brandtzaeg P. Cytokineregulated expression of E-selectin, intercellular adhesion molecule-1 (ICAM-1), and vascular cell adhesion molecule-1 (VCAM-1) in human microvascular endothelial cells. J Immunol. 1996;156:2558-65.

31. Cavalcanti YV, Brelaz MC, Neves JK, Ferraz JC, Pereira VR. Role of TNF-alpha, IFN-gamma, and IL-10 in the development of pulmonary tuberculosis. Pulm Med. 2012;2012:745483.

32. Robbins JR, Zeldovich VB, Poukchanski A, Boothroyd JC, Bakardjiev Al. Tissue barriers of the human placenta to infection with Toxoplasma gondii. Infect Immun. 2012;80:418-28.

33. Yamane I, Kitani H, Kokuho T, Shibahara T, Haritani M, Hamaoka T, et al. The inhibitory effect of interferon gamma and tumor necrosis factor alpha on intracellular multiplication of Neospora caninum in primary bovine brain cells. J Vet Med Sci. 2000;62:347-51.

34. Jesus EE, Pinheiro AM, Santos AB, Freire SM, Tardy MB, El-Bacha RS, et al. Effects of IFN-gamma, TNF-alpha, IL-10 and TGF-beta on Neospora caninum infection in rat glial cells. Exp Parasitol. 2013;133:269-74.

35. Jauniaux E, Gulbis B, Schandene L, Collette J, Hustin J. Molecular interactions during pregnancy: distribution of interleukin-6 in maternal and embryonic tissues during the first trimester. Mol Hum Reprod. 1996:2:239-43.

36. Diehl S, Rincón M. The two faces of IL-6 on Th1/Th2 differentiation. Mol Immunol. 2002;39:531-6.

37. Pinheiro AM, Costa SL, Freire SM, Ribeiro CS, Tardy M, El-Bacha RS, et al. Neospora caninum: early immune response of rat mixed glial cultures after tachyzoites infection. Exp Parasitol. 2010;124:442-7.

38. Almería S, Araujo RN, Darwich L, Dubey JP, Gasbarre LC. Cytokine gene expression at the materno-foetal interface after experimental Neospora caninum infection of heifers at 110 days of gestation. Parasite Immunol. 2011;33:517-23.

39. Liao $Y$, Zhang $Y$, Liu $X, L u Y$, Zhang $L, X i T$, et al. Maternal murine cytomegalovirus infection during pregnancy up-regulates the gene expression of Toll-like receptor 2 and 4 in placenta. Curr Med Sci. 2018;38:632-9.

40. Gayle DA, Beloosesky R, Desai M, Amidi F, Nuñez SE, Ross MG. Maternal LPS induces cytokines in the amniotic fluid and corticotropin releasing hormone in the fetal rat brain. Am J Physiol Regul Integr Comp Physiol. 2004;286:1024-9.

41. Ashdown H, Dumont Y, Ng M, Poole S, Boksa P, Luheshi G. The role of cytokines in mediating effects of prenatal infection on the fetus: implications for schizophrenia. Mol Psychiatry. 2006;11:47.

42. Beloosesky R, Gayle DA, Amidi F, Nunez SE, Babu J, Desai M, et al. $\mathrm{N}$-Acetyl-cysteine suppresses amniotic fluid and placenta inflammatory cytokine responses to lipopolysaccharide in rats. Obstet Gynecol. 2006;194:268-73.

43. Arranz-Solís D, Benavides J, Regidor-Cerrillo J, Horcajo P, Castaño P, del Carmen Ferreras M, et al. Systemic and local immune responses in sheep after Neospora caninum experimental infection at early, mid and late gestation. Vet Res. 2016:47:2.

44. Rosbottom A, Gibney H, Kaiser P, Hartley C, Smith RF, Robinson R, et al. Up regulation of the maternal immune response in the placenta of cattle naturally infected with Neospora caninum. PLoS ONE. 2011;6:e15799.

45. Almería S, Serrano-Perez B, Darwich L, Domingo M, Mur-Novales R, Regidor-Cerrillo J, et al. Foetal death in naive heifers inoculated with Neospora caninum isolate Nc-Spain7 at 110 days of pregnancy. Exp Parasitol. 2016;168:62-9.

46. Baszler TV, Long MT, McElwain TF, Mathison BA. Interferon-gamma and interleukin-12 mediate protection to acute Neospora caninum infection in BALB/c mice. Int J Parasitol. 1999;29:1635-46.

47. Etienne-Manneville S, Chaverot N, Strosberg AD, Couraud PO. ICAM1-coupled signaling pathways in astrocytes converge to cyclic AMP response element-binding protein phosphorylation and TNF-alpha secretion. J Immunol. 1999;163:66874. 
48. Deisher TA, Haddix TL, Montgomery KF, PohIman TH, Kaushansky K, Harlan JM. The role of protein kinase $C$ in the induction of VCAM-1 expression on human umbilical vein endothelial cells. FEBS Lett. 1993;331:285-90.

49. Silva LM, Vila-Viçosa MJ, Cortes HC, Taubert A, Hermosilla C. Suitable in vitro Eimeria arloingi macromeront formation in host endothelial cells and modulation of adhesion molecule, cytokine and chemokine gene transcription. Parasitol Res. 2015;114:113-24.

50. Maksimov P, Hermosilla C, Kleinertz S, Hirzmann J, Taubert A. Besnoitia besnoiti infections activate primary bovine endothelial cells and promote PMN adhesion and NET formation under physiological flow condition. Parasitol Res. 2016;115:1991-2001.

51. Zhang D, Chen L, Li S, Gu Z, Yan J. Lipopolysaccharide (LPS) of Porphyromonas gingivalis induces IL-1 $\beta$, TNF- $a$ and IL-6 production by THP-1 cells in a way different from that of Escherichia coli LPS. Innate Immun. 2008;14:99-107.

52. Castillo C, Muñoz L, Carrillo I, Liempi A, Medina L, Galanti N, et al. Ex vivo infection of human placental chorionic villi explants with Trypanosoma cruzi and Toxoplasma gondii induces different Toll-like receptor expression and cytokine/chemokine profiles. Am J Reprod Immunol. 2017:78:12660.

53. Castillo C, Muñoz L, Carrillo I, Liempi A, Medina L, Galanti N, et al. Toll-like receptor-2 mediates local innate immune response against Trypanosoma cruzi in ex vivo infected human placental chorionic villi explants. Placenta. 2017;60:40-6.

54. Regidor-Cerrillo J, Gomez-Bautista M, Sodupe I, Aduriz G, Alvarez-Garcia $G$, Del Pozo I, et al. In vitro invasion efficiency and intracellular proliferation rate comprise virulence-related phenotypic traits of Neospora caninum. Vet Res. 2011;42:41.

55. Almería S, Serrano-Perez B, López-Gatius F. Immune response in bovine neosporosis: protection or contribution to the pathogenesis of abortion. Microb Pathog. 2017;109:177-82.
56. Regidor-Cerrillo J, Gómez-Bautista M, Pereira-Bueno J, Adúriz G, NavarroLozano V, Risco-Castillo V, et al. Isolation and genetic characterization of Neospora caninum from asymptomatic calves in Spain. Parasitology. 2008;135:1651-9.

57. Rojo-Montejo S, Collantes-Fernández E, Regidor-Cerrillo J, Álvarez-García G, Marugan-Hernández V, Pedraza-Díaz S, et al. Isolation and characterization of a bovine isolate of Neospora caninum with low virulence. Vet Parasitol. 2009;159:7-16.

58. Pérez-Zaballos FJ, Ortega-Mora LM, Álvarez-García G, Collantes-Fernández E, Navarro-Lozano V, García-Villada L, et al. Adaptation of Neospora caninum isolates to cell-culture changes: an argument in favor of its clonal population structure. J Parasitol. 2005;91:507-10.

59. Bridger PS, Menge C, Leiser R, Tinneberg HR, Pfarrer CD. Bovine caruncular epithelial cell line (BCEC-1) isolated from the placenta forms a functional epithelial barrier in a polarised cell culture model. Placenta. 2007;28:1110-7.

60. Hambruch N, Haeger JD, Dilly M, Pfarrer C. EGF stimulates proliferation in the bovine placental trophoblast cell line F3 via Ras and MAPK. Placenta. 2010;31:67-74.

61. Menzies M, Ingham A. Identification and expression of Toll-like receptors 1-10 in selected bovine and ovine tissues. Vet Immunol Immunopathol. 2006;109:23-30.

62. Puech C, Dedieu L, Chantal I, Rodrigues V. Design and evaluation of a unique SYBR Green real-time RT-PCR assay for quantification of five major cytokines in cattle, sheep and goats. BMC Vet Res. 2015;11:65.

63. Schmittgen TD, Livak KJ. Analyzing real-time PCR data by the comparative C(T) method. Nat Protoc. 2008;3:1101-8.
Ready to submit your research? Choose BMC and benefit from:

- fast, convenient online submission

- thorough peer review by experienced researchers in your field

- rapid publication on acceptance

- support for research data, including large and complex data types

- gold Open Access which fosters wider collaboration and increased citations

- maximum visibility for your research: over 100M website views per year

At BMC, research is always in progress.

Learn more biomedcentral.com/submissions 